\title{
Krajowa Rada ds. Onkologii
}

Minister Zdrowia — zarządzeniem z 10 lutego 2015 roku — powołał Krajową Radę ds. Onkologii, która jest organem opiniodawczo-doradczym. Najważniejszym zadaniem Krajowej Rady ds. Onkologii jest opracowanie i przedstawienie Ministrowi Zdrowia projektu Narodowego Programu Chorób Nowotworowych na okres 2016-2024. Poza tym zadania obejmują występowanie do Ministra Zdrowia z wnioskami dotyczącymi zapobieganiu nowotworom oraz działaniami zwiększającymi efektywność opieki onkologicznej. W skład Krajowej Rady ds. Onkologii wchodzą:

Przewodniczący:

— prof. dr hab. n. med. Maciej Krzakowski — konsultant krajowy w dziedzinie onkologii klinicznej, Prezes Polskiego Towarzystwa Onkologii Klinicznej;

Wiceprzewodniczący:

- Anna Łukasik - Podsekretarz Stanu w Ministerstwie Zdrowia;

- Piotr Warczyński — Podsekretarz Stanu w Ministerstwie Zdrowia;

Członkowie:

- dr hab. n. med. Magdalena Bielska-Lasota - Narodowy Instytut Zdrowia Publicznego, Państwowy Zakład Higieny;

— drhab. n. med. Rafał Dziadziuszko — konsultant krajowy w dziedzinie radioterapii onkologicznej;

- prof. dr hab. n. med. Jacek Fijuth - Przewodniczący Polskiego Towarzystwa Onkologicznego;

- dr hab. n. med. Stanisław Góźdź - konsultant wojewódzki w dziedzinie onkologii klinicznej dla województwa świętokrzyskiego;

- lek. Agnieszka Jankowska-Zduńczyk — konsultant krajowy w dziedzinie medycyny rodzinnej;

- prof. dr hab. n. med. Jacek Jassem - Członek Zarządu Polskiego Towarzystwa Onkologicznego;

- drn. med. Anna Koper — konsultant krajowy w dziedzinie pielęgniarstwa onkologicznego;

- prof. dr hab. n. med. Jerzy Kowalczyk - konsultant krajowy w dziedzinie onkologii i hematologii dziecięcej;

— dr n. med. Janusz Meder — Prezes Polskiej Unii Onkologii;

— prof. dr hab. n. med. Jarosław Peregud-Pogorzelski — Przewodniczący Oddziału Szczecińskiego Polskiego Towarzystwa Pediatrycznego;
— dr n. med. Jadwiga Pyszkowska — Prezes Polskiego Towarzystwa Medycyny Paliatywnej;

— prof. dr hab. n. med. Jarosław Reguła — konsultant krajowy w dziedzinie gastroenterologii;

— drn. med.Wojciech Rogowski — konsultant wojewódzki ds. onkologii klinicznej dla województwa warmińsko-mazurskiego;

— prof.dr hab. n. med. Piotr Rutkowski — Prezes Polskiego Towarzystwa Chirurgii Onkologicznej;

— prof. dr hab. n. med. Maria Sąsiadek — konsultant krajowy w dziedzinie genetyki;

— prof. dr hab. n. med. Krzysztof Warzocha - Dyrektor Centrum Onkologii — Instytutu im. Marii Skłodowskiej-Curie oraz Instytutu Hematologii i Transfuzjologii;

— dr n. med. Bogdan Wojtyniak - Zastępca Dyrektora ds. Szkolenia Podyplomowego i Współpracy w zakresie Zdrowia Publicznego, Narodowy Instytut Zdrowia Publicznego, Państwowy Zakład Higieny;

- prof. dr hab. n. med. Dariusz Wołowiec - konsultant krajowy w dziedzinie hematologii;

— prof. dr hab. n. med. Witold Zatoński - Kierownik Zakładu Epidemiologii i Prewencji Nowotworów Centrum Onkologii — Instytutu im. Marii Skłodowskiej-Curie w Warszawie;

- Szymon Chrostowski — Prezes Polskiej Koalicji Pacjentów Onkologicznych;

- Barbara Więckowska - Dyrektor Departamentu Analiz i Strategii Ministerstwa Zdrowia;

- Krzysztof Bąk - Dyrektor Biura Prasy i Promocji Ministerstwa Zdrowia;

- Joanna Kilkowska - Dyrektor Departamentu Polityki Zdrowotnej Ministerstwa Zdrowia.

Najważniejszym zadaniem Krajowej Rady ds. Onkologii jest przygotowanie nowej wersji Narodowego Programu Zwalczania Chorób Nowotworowych, która zakłada zmniejszenie tempa wzrostu zachorowalności na nowotwory oraz osiągnięcie średnich wskaźników europejskich w zakresie wykrywania i leczenia. Działania koncentrować się będą na poprawieniu skuteczności profilaktyki pierwotnej oraz badań przesiewowych i wczesnego wykrywania, optymalizacji systemu zbierania informacji na temat zachorowalności i innych wskaźników epidemiologicznych, szkoleniu przeddyplomowym i podyplomowym wszystkich zawodów 
medycznych, upowszechnianiu w społeczeństwie wiedzy na temat zapobiegania i rozpoznawania nowotworów, opracowaniu zasad referencyjności i oceny jakości postępowania przeciwnowotworowego oraz zmian organizacyjnych (w tym — w zakresie finansowania). Kontynuowanych będzie wiele zadań, które realizowane były w poprzedniej edycji Narodowego Programu Chorób Nowotworowych (np. inwestycje w zakresie wyposażenia ośrodków onkologicznych, programy opieki nad rodzinami wysokiego ryzyka i dziedzicznie uwarunkowanego zachorowania na nowotwory złośliwe, działania w kierunku poprawy standardów diagnostyki patomorfologicznej i molekularnej).

W związku z wymienionymi wyżej zadaniami w ramach Krajowej Rady ds. Onkologii powołane zostały zespoły, które zajmować się będą:

1. profilaktyką (przewodniczący - prof. Witold Zatoński, prof. Jarosław Reguła);

2. kształceniem przeddyplomowym (przewodniczący — prof. Jacek Jassem);
3. optymalizacją świadczeń zdrowotnych (przewodniczący — prof. Krzysztof Warzocha);

4. standaryzacją i jakością leczenia (przewodniczący - prof. Jerzy Kowalczyk, prof. Piotr Rutkowski);

5. monitorowaniem efektów zdrowotnych programu (przewodniczący - prof. Magdalena Bielska-Lasota, dr Janusz Meder);

6. diagnostyką patomorfologiczną i genetyczną (przewodniczący - prof. Maria Sąsiadek).

Wymienione zespoły składają się zarówno z Członków Krajowej Rady ds. Onkologii, jak również z zaproszonych ekspertów. Przyjęte zostały propozycje realizacji zadań i harmonogramów, które przedstawili Przewodniczący wymienionych wyżej zespołów.

W niedługim czasie zostaną przedstawione szczegółowe rozwiązania w zakresie poszczególnych zadań, tak aby możliwe było rozpoczęcie realizacji Narodowego Programu Chorób Nowotworowych.

Redakcja 